\title{
Microhabitat and shrimp abundance within a Norwegian cold-water coral ecosystem
}

\author{
A. Purser ${ }^{1}$, J. Ontrup ${ }^{2}$, T. Schoening ${ }^{2}$, L. Thomsen ${ }^{1}$, R. Tong ${ }^{1}$, V. Unnithan ${ }^{1}$, and T. W. Nattkemper ${ }^{2}$ \\ ${ }^{1}$ Jacobs University Bremen, Campus Ring 1, 28759 Bremen, Germany \\ ${ }^{2}$ Bielefeld University, Faculty of Technology, Biodata Mining Group, P.O. Box 100131, 33501 Bielefeld, Germany
}

Correspondence to: A. Purser (a.purser@jacobs-university.de)

Received: 6 December 2012 - Published in Biogeosciences Discuss.: 22 February 2013

Revised: 24 June 2013 - Accepted: 26 July 2013 - Published: 3 September 2013

\begin{abstract}
Cold-water coral (CWC) reefs are heterogeneous ecosystems comprising numerous microhabitats. A typical European CWC reef provides various biogenic microhabitats (within, on and surrounding colonies of coral species such as Lophelia pertusa, Paragorgia arborea and Primnoa resedaeformis, or formed by their remains after death). These microhabitats may be surrounded and intermixed with non-biogenic microhabitats (soft sediment, hard ground, gravel/pebbles, steep walls). To date, studies of distribution of sessile fauna across $\mathrm{CWC}$ reefs have been more numerous than those investigating mobile fauna distribution.

In this study we quantified shrimp densities associated with key CWC microhabitat categories at the Røst Reef, Norway, by analysing image data collected by towed video sled in June 2007. We also investigated shrimp distribution patterns on the local scale $(<40 \mathrm{~cm})$ and how these may vary with microhabitat.

Shrimp abundances at the Røst Reef were on average an order of magnitude greater in biogenic reef microhabitats than in non-biogenic microhabitats. Greatest shrimp densities were observed in association with live Paragorgia arborea microhabitat (43 shrimp $\left.\mathrm{m}^{-2}, \mathrm{SD}=35.5\right)$, live Primnoa resedaeformis microhabitat (41.6 shrimp $\mathrm{m}^{-2}$, $\mathrm{SD}=26.1)$ and live Lophelia pertusa microhabitat $(24.4$ shrimp $\left.\mathrm{m}^{-2}, \mathrm{SD}=18.6\right)$. In non-biogenic microhabitat, shrimp densities were $<2$ shrimp $\mathrm{m}^{-2}$. CWC reef microhabitats appear to support greater shrimp densities than the surrounding non-biogenic microhabitats at the Røst Reef, at least at the time of survey.
\end{abstract}

\section{Introduction}

Cold-water coral (CWC) ecosystems have been subject to much study throughout the last decade (Fosså et al., 2002; Freiwald et al., 2002; Roberts et al., 2006; Reveillaud et al., 2008; White et al., 2012). Commonly identified as local biodiversity hotspots (Weaver et al., 2004; Turley et al., 2007; Levin and Sibuet, 2012), these ecosystems develop over time with the growth of complex biogenic reef structures, formed from the aragonite skeletons of scleractinian coral species. In European waters, Lophelia pertusa, Fig. 1(Fosså et al., 2005; Roberts et al., 2009), is commonly the key frameworkbuilding species.

Cold-water coral reefs are often associated with elevated seabed features or areas where hydrodynamic conditions assist delivery of large volumes of refractory material, or pulses of labile material to the benthic ecosystem (Duineveld et al., 2004; Kiriakoulakis et al., 2005; Thiem et al., 2006; Kiriakoulakis et al., 2007; Davies et al., 2009; Van Oevelen et al., 2009; Rüggeberg et al., 2010; Wagner et al., 2011; Duineveld et al., 2012). Sizable reef structures can develop with successive generations of coral polyp growth (Mortensen et al., 1995; De Mol., 2002; Dorschel et al., 2005; Wheeler et al., 2007). The aragonite skeleton of the polyps increases habitat complexity both at and above the seafloor (Rogers, 1999). Dead coral polyps provide hard substrate for sessile filter-feeding organisms (López Correa et al., 2004), with the complexity of the reef morphology providing refuge for mobile organisms such as fish (Husebø et al., 2002; Costello et al., 2005; Ross and Quattrini, 2007; Ballion et al., 2012; D’Onghia et al., 2012), shrimp and other crustaceans (Reed et al., 1982; Mortensen et al., 1995; Krieger and Wing., 2002; 

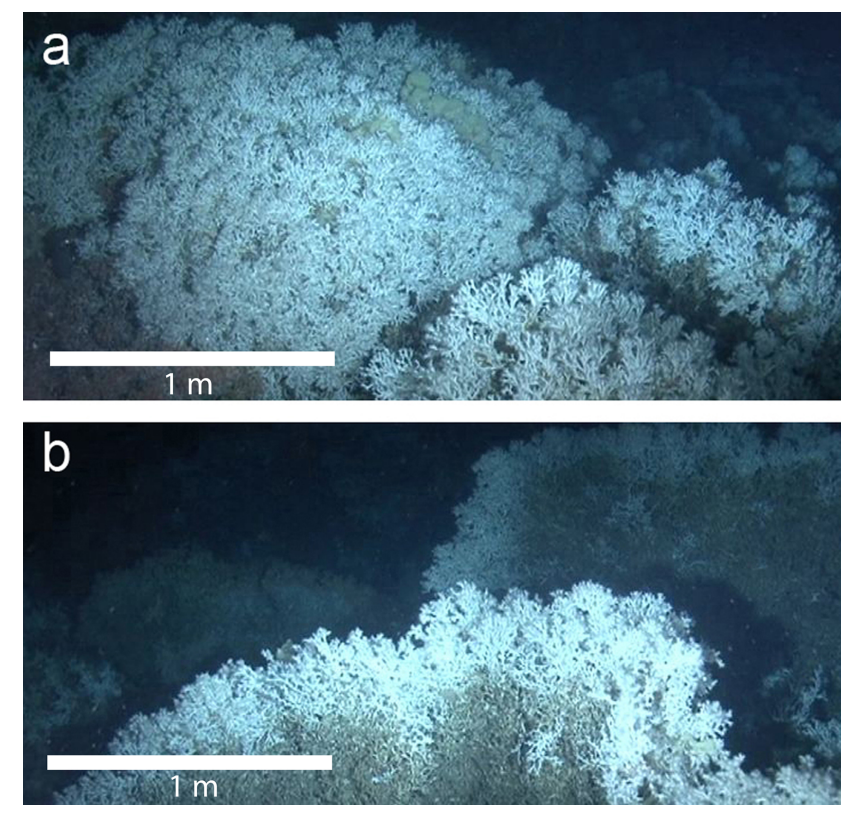

Fig. 1. Lophelia pertusa colony at the Røst Reef, Norway. (a) typical "cauliflower" growth form at the Røst Reef, with live polyps facing into the prevalent current direction. (b) The downstream side of the "cauliflower" reef structure. The upper $\sim 25 \mathrm{~cm}$ of each cauliflower is made up of living Lophelia pertusa; the remainder the dead skeletal structure of previous polyp generations. Image courtesy of IFM-GEOMAR JAGO team.

Roberts et al., 2008; Le Guilloux et al., 2010; D’Onghia et al., 2012). Local hydrodynamic flow may be influenced by coral structure, enhancing or reducing local depositional rates across a reef, or entrapping suspended material in turbidity loops above the reef structure (Mortensen et al., 1995, 2001; White, 2007; Wagner et al., 2011). Sediments dropping from suspension within and surrounding coral provide further microhabitats for meiofauna (Raes and Vanreusel, 2006; Bongiorni et al., 2010).

In addition to scleractinians, gorgonian corals are found within many European CWC ecosystems. Common species include Primnoa resedaeformis and Paragorgia arborea (Mortensen et al., 1995; Herrera et al., 2012; Tong et al., 2012a). Growth morphologies of these species differ, with Primnoa resedaeformis colonies often comprising a number of branches draped across or close to the underlying substrate, whereas Paragorgia arborea colonies stand more erect, often facing fan-like into the direction of prevalent flow (Mortensen and Buhl-Mortensen, 2005) (Fig. 2).

Methodologies for quantitatively assessing CWC reef biodiversity have improved over time. Early studies using dredge sampling (Jensen and Frederiksen, 1992) gave way to campaigns employing Van Veen, box core or video grab sampling techniques (Mortensen et al., 2000; Mortensen and Fosså, 2006; Henry and Roberts, 2007; Henry et al., 2010). Although adept at collecting data on sessile species' abun-
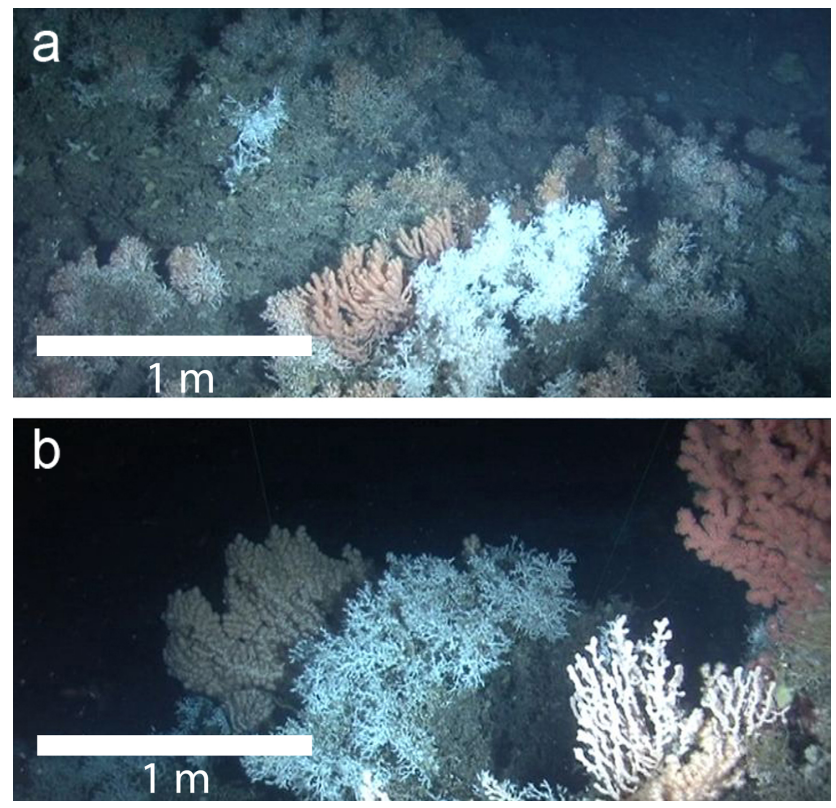

Fig. 2. Typical Primnoa resedaeformis and Paragorgia arborea colonies at the Røst Reef, Norway. (a) P. resedaeformis, the orange branching gorgonian in the lower centre of the image. Often located in cracks in the Lophelia pertusa structure or on the walls of coral blocks. (b) Three colonies of $P$. arborea. A large salmon-coloured colony in the middle distance, a pink colony on the top right and a salmon-coloured colony on the bottom right. The bottom-right colony has its polyps retracted.

dances, mobile fauna are often missed or under-sampled by this approach. Analysis of video data, collected by remotely operated vehicle (ROV), submarine or video sled can gather data on the distribution of fauna over larger areas, and with mobile fauna with more success than grab sampling, although video resolution and illumination can limit the level of taxonomical identification possible (Mortensen et al., 1995; Purser et al., 2009; Schoening et al., 2012). The illumination required to collect video data may also influence faunal behaviour (Trenkel et al., 2004). At CWC reef sites, video studies have focused primarily on occurrence and distribution of sessile species (Mortensen et al., 1995; Henry, 2001; Metaxas and Davis, 2005; Orejas et al., 2008; Purser et al., 2009), with fewer studies quantifying mobile macrofauna across CWC reef microhabitats (Jonsson et al., 2004; Roberts et al., 2008; Le Guilloux et al., 2010; Lessard-Pilon et al., 2010; D’Onghia et al., 2011).

Aside from fish (Mortensen et al., 1995; Costello et al., 2005; Wheeler et al., 2005; Söffker et al., 2011) and the larger crustaceans ( $>5 \mathrm{~cm}$ ) (Mortensen et al., 1995), shrimp are amongst the mobile fauna reported in association with CWC scleractinian corals at northeast Atlantic seamounts (Henry and Roberts, 2007), in the Gulf of Mexico (Cordes et al., 2008; Lessard-Pilon et al., 2010) or with gorgonian corals from Atlantic Canada (Krieger and Wing, 2002; 


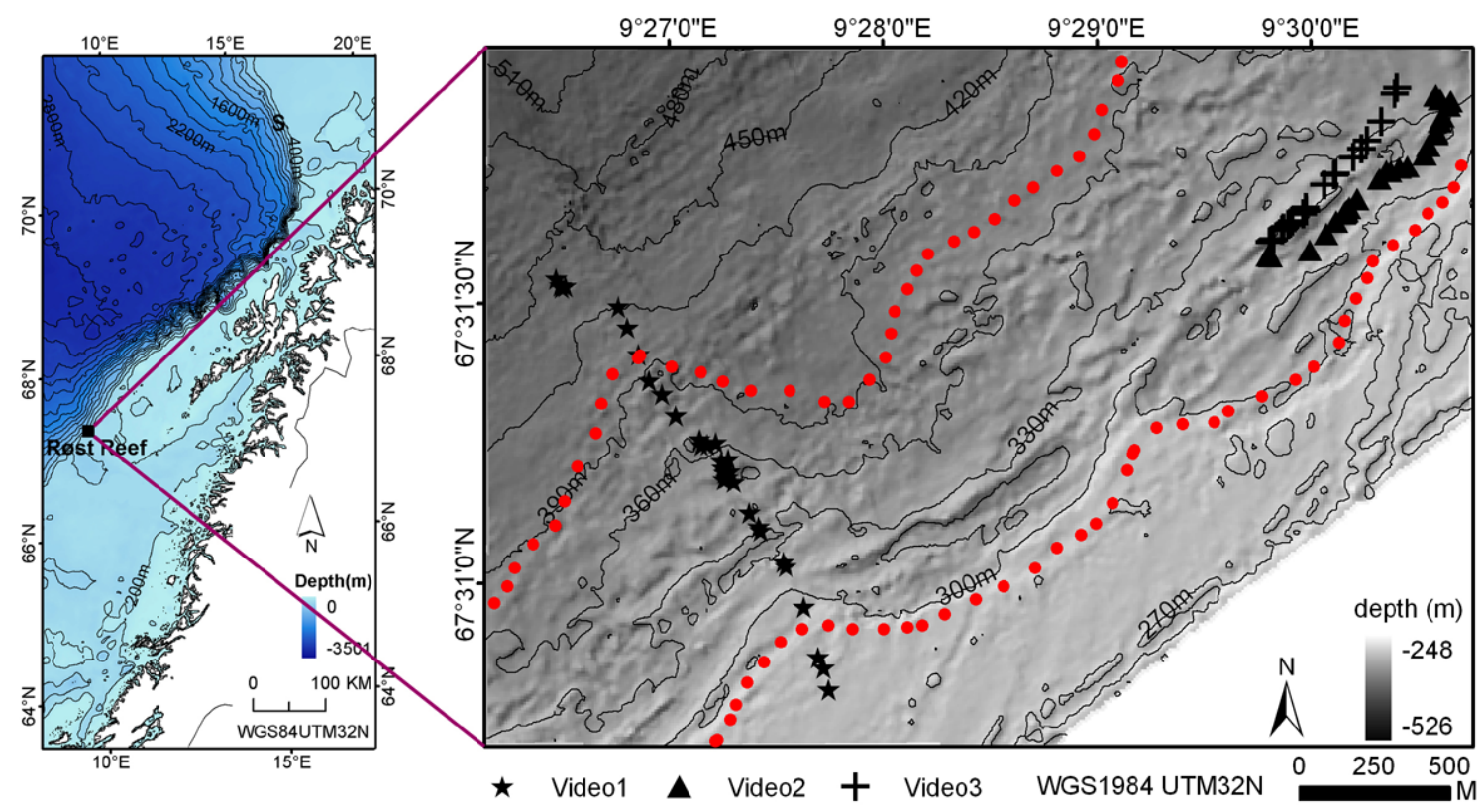

Fig. 3. Bathymetric map showing the location of the Røst Reef on the Norwegian margin, and the location of the three video transects analysed in this study. Red dots delineate reef microhabitat areas.

Buhl-Mortensen and Mortensen, 2004a). From the CWC scleractinian reefs of the Norwegian margin and fjords, Pandalus borealis, Pandalus montagui (Jonsson et al., 2004), Pandalus propinquus, Lebbeus polaris, Eualis gaimardii and Caridion gordoni (Dons, 1944; Burdon-Jones and TambsLyche, 1960; Jensen and Frederiksen, 1992; summarised in Mortensen and Fosså, 2006; Jonsson et al., 2004) are the most commonly found shrimp species. The relationship between particular shrimp species and scleractinian or gorgonian corals is uncertain. The hypothesis that shrimp are facultative commensals on the associated coral species has been raised (Buhl-Mortensen and Mortensen, 2004b).

To date, shrimp abundances across the various microhabitats found at CWC reefs have not been studied in detail. Previous video studies reporting densities of mobile fauna associated with microhabitats such as living coral reef, dead coral framework or dead coral rubble have either focused on fauna larger than the majority of shrimp species (Mortensen et al., 1995) or determined densities from discreet patch locations within reefs (Jonsson et al., 2004). In this study we investigate the distribution of shrimp across the CWC microhabitats from video sled data collected at the Røst Reef complex, Norway. The overall aim of the investigation was to see whether or not shrimp abundances were significantly different in the different microhabitats of the CWC reef - such as within and above live Lophelia pertusa, or in association with the coral rubble area surrounding the main structural reef. Video data were also collected from the surrounding seafloor non-biogenic microhabitats, such as rubble/pebble covered areas and areas of exposed hard ground. In addition to quantifying shrimp densities associated with these microhabitats, the spacing of the shrimp within the habitats was also investigated. Here we determined whether shrimp were randomly distributed within a microhabitat, or more prone to either clustering or maintaining a certain spacing distance from each other. By carrying out this distribution analysis we were interested in determining whether or not there may be a behavioural change in shrimp related to the microhabitat.

\section{Methods}

\subsection{Location of study - the Røst Reef}

The Røst Reef complex, the largest discovered worldwide to date (Fosså et al., 2002; Nordgulen et al., 2006; Wehrmann et al., 2009; Fosså et al., 2010; Tong et al., 2012a), was the focus of this study. The complex is situated on the edge of the continental shelf, and is marked by vigorous Lophelia pertusa scleractinian coral growth on a series of seafloor crests formed by the Trænadjupet landslide during the Cenozoic (Laberg and Vorren, 2000). Between these scleractinian reef crests are regions of coral rubble and areas of low density Lophelia pertusa coverage on dead, exposed coral framework (Wehrmann et al., 2009) with the gorgonian coral species Primnoa arborea and Paragorgia arborea also abundant (Tong et al., 2012a).

\subsection{Video data}

Data were collected from three video sled traverses (Fig. 3), cross-cutting the coral dense ridge crests, less populated 

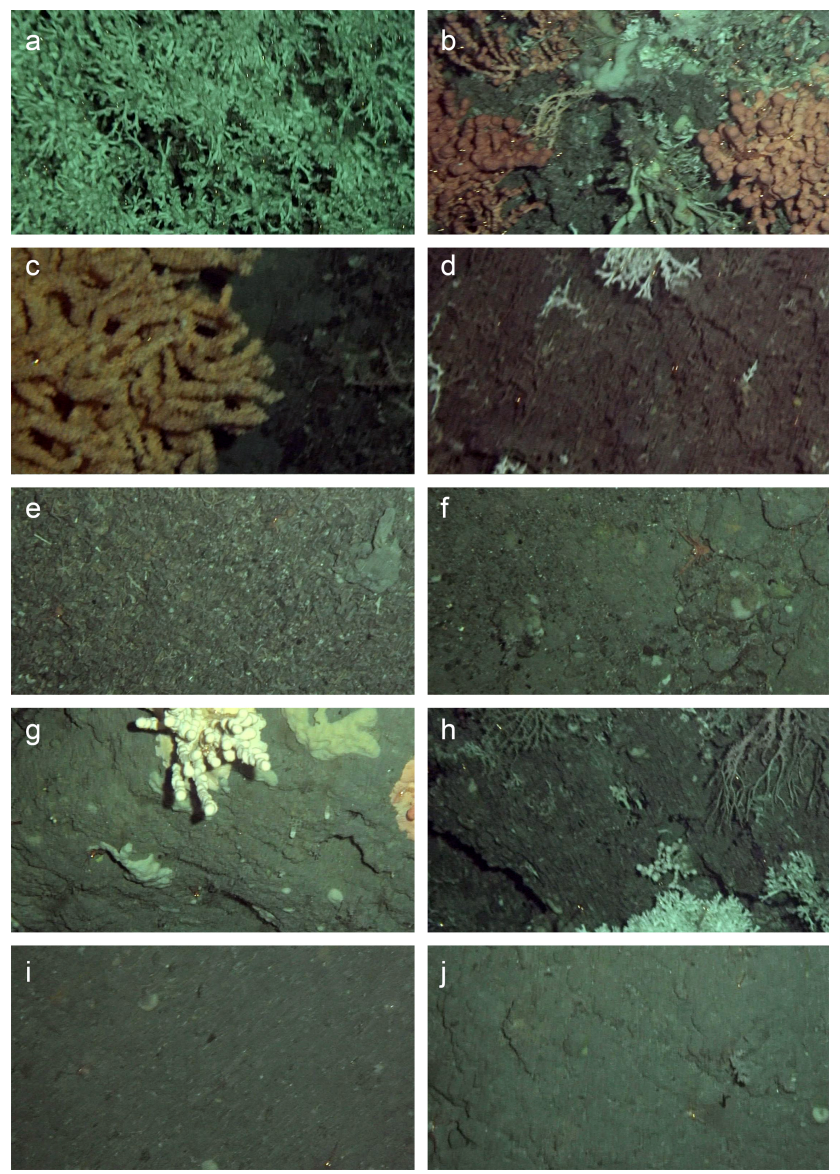

Fig. 4. Habitat categories used in this study. (a) Live Lophelia pertusa, (b) live Paragorgia arborea (left and right of image), (c) live Primnoa resedaeformis (left of image), (d) dead scleractinian structure, (e) coral rubble, (f) gravel/pebbles, (g) wall, (h) dead gorgonian (right of image), (i) soft seabed and (j) hard ground.

flanks and sparsely populated intermediate areas during the ARKXXII/1a RV Polarstern cruise (Klages and Thiede, 2011) of 2007. The video sled consisted of a metal frame approximately $1 \mathrm{~m}$ in area, onto which was mounted two vertically downward facing camera housings and a light source. One camera housing contained a low-resolution camera which could be viewed directly by the winch operator to allow for vertical positioning of the video sled above the seafloor. The second camera housing contained a Sony HD video camera which was used to film the seabed from an altitude of $\sim 3 \mathrm{~m}$, with an average area of $\sim 1 \mathrm{~m}^{2}( \pm 25 \%)$ coverage recorded. The video transects were planned to provide data from typical microhabitat categories common at CWC coral reefs on the Norwegian margin (see Sect. 2.3). Video sled transect data have recently been used in a similar ecosystem in the Mediterranean for bethopelagic fauna quantification (D’Onghia et al., 2011).

Two image frames per second were exported from the video camera and imported with a resolution of $1920 \times 1080$ pixels into the web-based image annotation platform BIIGLE (Bio-Image Indexing, Graphical Labelling and Exploration) (Ontrup et al., 2009; Schoening et al., 2009; Purser et al., 2009; Bergmann et al., 2011). The seabed overlap of successive image frames was $\sim 20 \%$. The area of seafloor covered by the extracted images was estimated from the assumption that the average diameter of a Lophelia pertusa polyp cup is $1 \mathrm{~cm}$ (based on box core and submarine samples collected during the cruise). From this analysis, seabed area covered by images containing Lophelia pertusa was generally $\sim 1 \mathrm{~m}^{2}$. Throughout the sampling, effort was made to maintain the camera at the same height above the seafloor, and therefore seafloor coverage in images containing no Lophelia pertusa was assumed to also be $1 \mathrm{~m}^{2}$. Prior to analysis, the image frames were checked for suitability, with those covering a seabed area of $<0.75 \mathrm{~m}^{2}$ or $>1.25 \mathrm{~m}^{2}$ and those too blurred for analysis discarded - these frames representing images extracted from the video during periods of camera heave, the result of wave action or manual movement of the camera to avoid seafloor obstacles..

\subsection{Microhabitat characterisation and shrimp labelling}

Ten microhabitat categories were investigated in this study (Fig. 4): live Lophelia pertusa (a), live Paragorgia arborea (b), live Primnoa resedaeformis (c), dead structure (d), coral rubble (e), gravel/pebbles (f), wall (g), dead gorgonian (h), soft seabed (i) and hard ground (j). These microhabitat categories were selected as all were previously reported for the Røst Reef and the Norwegian margin reefs in general (Mortensen et al., 1995; Wehrmann et al., 2009; Tong et al., 2012b).

In each image the main microhabitat category was logged (i.e. that with the greatest seafloor coverage area) via the BIIGLE system. Additionally, presence/absence of each of the other microhabitat categories within each image was also noted.

After identifying each microhabitat in an image, the coordinates of each visible shrimp were also determined. Due to the high reflectivity of the eyes of shrimp, spotting these on the image frames was not a significant problem (Fig. 5). As the video sled filmed the seabed from above, the majority of shrimp were observed from above. The eyes of each shrimp were separated from each other by $\sim 5 \mathrm{~mm}$ (approx. 5-10 pixels). To assign coordinates for each shrimp individual in an image, the midpoint between the shrimp's eyes was marked into the BIIGLE system as the point location of the shrimp (Fig. 5). Due to the resolution of data, no attempt was made to differentiate shrimp species. 
Table 1. Shrimp densities observed across the various habitat categories. Mean and median distance between individual shrimp observed in association with each habitat category are also given. Mean minimum and maximum distances between nearest neighbours are also shown.

\begin{tabular}{|c|c|c|c|c|c|c|c|c|c|c|}
\hline Habitat & $\begin{array}{l}\text { Number of } \\
\text { frames }\end{array}$ & Shrimps $\mathrm{m}^{-2}$ & SD & $\begin{array}{l}\text { Mean } \\
\text { distance } \\
\text { nearest } \\
\text { neighbour } \\
(\mathrm{mm})\end{array}$ & SD & $\begin{array}{l}\text { Median } \\
\text { distance } \\
\text { nearest } \\
\text { neighbour } \\
(\mathrm{mm})\end{array}$ & $\begin{array}{l}\text { Mean } \\
\text { minimum } \\
\text { distance } \\
\text { nearest } \\
\text { neighbour } \\
(\mathrm{mm})\end{array}$ & SD & $\begin{array}{l}\text { Mean } \\
\text { maximum } \\
\text { distance } \\
\text { nearest } \\
\text { neighbour } \\
(\mathrm{mm})\end{array}$ & SD \\
\hline $\begin{array}{l}\text { Live } \\
\text { Lophelia }\end{array}$ & 365 & 24.41 & 18.64 & 11.08 & 5.81 & 10.07 & 4.65 & 4.38 & 24.45 & 11.42 \\
\hline $\begin{array}{l}\text { Live } \\
\text { Paragorgia }\end{array}$ & 8 & 43.00 & 35.58 & 10.92 & 6.22 & 7.92 & 3.62 & 2.29 & 24.95 & 13.99 \\
\hline $\begin{array}{l}\text { Live } \\
\text { Primnoa }\end{array}$ & 5 & 41.60 & 26.06 & 10.57 & 6.23 & 7.20 & 4.71 & 6.08 & 21.00 & 8.65 \\
\hline $\begin{array}{l}\text { Dead } \\
\text { structure }\end{array}$ & 779 & 8.70 & 7.80 & 15.27 & 11.97 & 13.54 & 8.52 & 10.74 & 29.79 & 20.94 \\
\hline $\begin{array}{l}\text { Coral } \\
\text { rubble }\end{array}$ & 699 & 1.45 & 2.52 & 7.13 & 13.64 & 0 & 5.41 & 12.57 & 10.55 & 19.35 \\
\hline $\begin{array}{l}\text { Dead } \\
\text { gorgonian }\end{array}$ & 0 & 0 & 0 & 0 & 0 & 0 & 0 & 0 & 0 & 0 \\
\hline $\begin{array}{l}\text { Gravel/ } \\
\text { pebbles }\end{array}$ & 1330 & 0.28 & 0.93 & 1.5 & 8.02 & 0 & 1.21 & 7.41 & 2.10 & 10.67 \\
\hline Wall & 318 & 1.95 & 3.38 & 6.67 & 12.73 & 0 & 4.50 & 10.68 & 11.50 & 20.65 \\
\hline Hard ground & 30 & 0.67 & 1.94 & 4.15 & 11.04 & 2.26 & 4.01 & 10.96 & 4.43 & 11.30 \\
\hline $\begin{array}{l}\text { Soft } \\
\text { sediment }\end{array}$ & 0 & 0 & 0 & 0 & 0 & 0 & 0 & 0 & 0 & 0 \\
\hline
\end{tabular}

\subsection{Statistics}

\subsubsection{Microhabitat category and shrimp density}

Video frames used covered a seabed area of $\sim 1 \mathrm{~m}^{2}$; therefore the number of shrimp logged in each image was assumed to be the minimum number of shrimp $\mathrm{m}^{-2}$. The complexity of microhabitats such as "live Lophelia pertusa" or "live Primnoa resedaeformis" renders it likely that the surface area available for shrimp to utilise is more extensive than in less complex microhabitats such as "coral rubble". Shrimp individuals may have been obscured from view by coral structure, small overhangs of larger pebbles or coral blocks in some microhabitats. The high heterogeneity of microhabitat categories within CWC reefs has been widely reported (Buhl-Mortensen et al., 2010; Gheerardyn et al., 2010; Tong et al., 2012a), with large variability in habitat complexity often occurring over scales of centimetres or metres. In this study we aim to show statistically whether or not these microhabitat categories are associated with different shrimp abundances.

The 10 microhabitat categories used in this study (see Sect. 2.3) are not of uniform spatial coverage within the Røst Reef. The gorgonian coral species Paragorgia arborea and Primnoa resedaeformis have a far less extensive spatial coverage than Lophelia pertusa (Tong et al., 2012a, b). These differences in coverage can make statistical analysis of video transect data problematic. To address this we grouped together the shrimp abundances observed in association with the various microhabitats into broader categories (with these broader categories covering more comparable spatial areas of reef) for statistical analysis. These broader categories were "live coral" (live Lophelia pertusa, live Paragorgia arborea, live Primnoa resedaeformis habitat categories), "dead coral" (dead structure and dead gorgonian categories), "coral rubble" or "non-biogenic habitats" (gravel/pebble, wall, soft sediment and hard ground categories). To determine whether or not shrimp densities varied significantly between these broader microhabitat categories a one-way ANOVA test with shrimp abundance as the dependant variable and habitat type as the investigated factor (four levels: live coral, dead coral, coral rubble, non-biogenic habitat) was used. Levene's test of homogeneity showed the data to be unequally distributed and therefore the robust Brown-Forsythe's $F$ (Brown and Forsythe, 1974) was reported in the analysis. A Bonferroni post hoc test was used to determine between which of the factor levels (broad microhabitat categories) differences in shrimp density were significant. For the ANOVA and post hoc tests the statistical package SPSS 17.0 was used. Effect size was also determined ( $\omega^{2}$ measure) (Field, 2009).

\subsubsection{Local-microhabitat-scale shrimp clustering patterns}

By analysing the distances between a shrimp and all its neighbours in a particular image frame a positive/negative association dependent on distance was determined by applying Ripley's L (Ripley, 1976). Ripley's L provides a statistical 
Table 2. Table summarising the local $(<40 \mathrm{~cm}$ scale) shrimp distribution patterns observed in image frames containing $>20$ shrimp. The number of frames taken above the $>50 \%$ live Lophelia pertusa, live Paragorgia arborea, live Primnoa resedaeformis and $>50 \%$ dead structure categories with $>20$ shrimp present is indicated. Insufficient shrimp were observed in association with the other habitat categories investigated to allow for computation of Ripley's L.

\begin{tabular}{|c|c|c|c|c|c|c|c|c|c|c|}
\hline $\begin{array}{l}\text { Main habi- } \\
\text { tat }\end{array}$ & $\begin{array}{l}\text { Number of } \\
\text { frames }\end{array}$ & $\begin{array}{l}\text { Mean } \\
\text { shrimp m }\end{array}$ & SD & $\begin{array}{l}\text { Number } \\
\text { frame }>20 \\
\text { shrimp m }{ }^{-2}\end{array}$ & $\begin{array}{l}\% \\
\text { Frames } \\
\text { of } \\
\text { habitat }\end{array}$ & $\begin{array}{l}\% \\
\text { Frames } \\
\text { with } \\
\text { shrimp } \\
\text { clus- } \\
\text { tering } \\
<10 \mathrm{~cm} \\
\text { scale }\end{array}$ & $\begin{array}{l}\% \\
\text { Frames } \\
\text { with } \\
\text { shrimp } \\
\text { clus- } \\
\text { tering } \\
>10 \mathrm{~cm} \\
\text { scale }\end{array}$ & $\begin{array}{l}\% \\
\text { Frames } \\
\text { with } \\
\text { regu- } \\
\text { larly } \\
\text { spaced } \\
\text { shrimp } \\
<10 \mathrm{~cm} \\
\text { scale }\end{array}$ & $\begin{array}{l}\% \\
\text { Frames } \\
\text { with } \\
\text { regu- } \\
\text { larly } \\
\text { spaced } \\
\text { shrimp } \\
>10 \mathrm{~cm} \\
\text { scale }\end{array}$ & $\begin{array}{l}\% \\
\text { Frames } \\
\text { with no } \\
\text { spatial } \\
\text { pattern }\end{array}$ \\
\hline $\begin{array}{l}\text { Live } \\
\text { Lophelia }\end{array}$ & 365 & 24.41 & 18.64 & 187 & 51.3 & 20.3 & 55.6 & 31.0 & 8.6 & 14.4 \\
\hline $\begin{array}{l}\text { Live } \\
\text { Paragorgia }\end{array}$ & 8 & 43.00 & 35.58 & 5 & 62.5 & 40.0 & 60.0 & 60.0 & 20.0 & 0 \\
\hline $\begin{array}{l}\text { Live } \\
\text { Primnoa }\end{array}$ & 5 & 41.60 & 26.06 & 4 & 80.0 & 50.0 & 75.0 & 25.0 & 0 & 0 \\
\hline $\begin{array}{l}\text { Dead struc- } \\
\text { ture }\end{array}$ & 779 & 8.70 & 7.80 & 71 & 9.1 & 42.6 & 75.7 & 10.0 & 7.1 & 12.9 \\
\hline
\end{tabular}

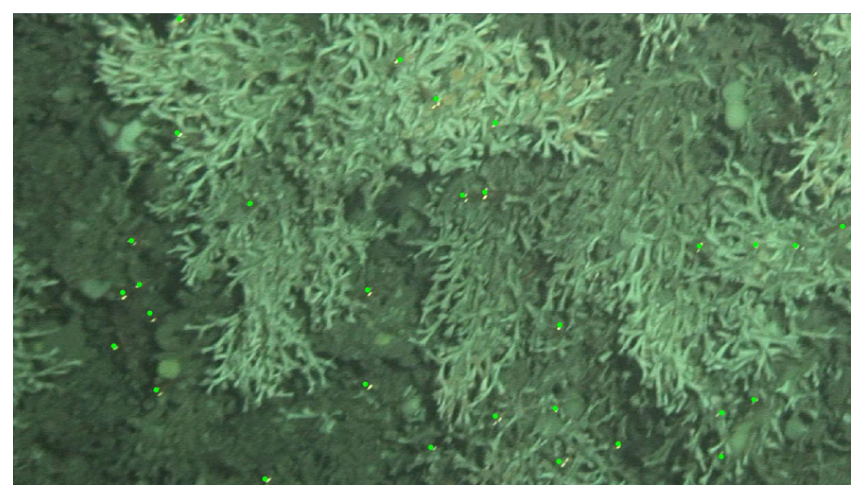

Fig. 5. Example frame extracted from the video sled data within the BIIGLE system. A number of slightly blurred shrimp eyes have been labelled in green. The image shows predominantly live Lophelia pertusa coral and a number of shrimp within and around the coral structures.

measure for the distribution of point items over different spatial scales. Image frames containing less than 20 shrimp were omitted from this test, as the method requires a minimum number of points (shrimp) for a valid outcome. Confidence envelopes $(95 \%)$ were computed by means of Monte Carlo sampling. Deviations from the confidence envelope by points within an image (shrimp locations) allows for rejection of the assumption that the point pattern is random on a particular spatial scale (the spatial scale at which distribution deviates from the confidence envelope) at the confidence level determined. The test also indicates whether or not these deviations represent a clustering of shrimp or a tendency for shrimp individuals to maintain a certain distance from each other. In this study complete spatial randomness was tested, with Ripley's L values computed up to a maximum of 540 pixels (half the smallest image frame axis, $\sim 40 \mathrm{~cm}$ ), therefore indicating whether there were any trends in distribution (shrimp clustering or spacing) over distances of up to $40 \mathrm{~cm}$.

\subsubsection{Habitat complexity and shrimp abundance}

In addition to logging the main microhabitat category visible in each analysed image frame, the number of additional microhabitat categories present in an image was also counted. The shrimp densities present in image frames containing 1 , 2,3 or $4+$ microhabitat categories was compared with a Kruskal-Wallis test to determine whether or not increase in the number of locally available $\left(<1 \mathrm{~m}^{2}\right.$ scale) microhabitat categories had an influence on shrimp abundance.

\section{Results}

A total of 18269 shrimp were manually labelled within 3534 analysed images. The main microhabitat category present in each image was identified and the number of shrimp in each image frame logged (Table 1). The median shrimp densities and quartile distribution of these observations is given in Fig. 6. Of the 10 microhabitat categories introduced in Sect. 2.3, eight were predominant habitat categories in at least one image frame. The microhabitat categories "dead gorgonian habitat" and "soft sediment", though present in some images, always had a seafloor coverage of less than at least one other microhabitat category.

\subsection{Shrimp densities and microhabitat}

There was a significant effect of primary microhabitat category on shrimp abundance, $F(3,3530)=503.8, p<0.001$, $\omega^{2}=0.26$ (Brown-Forsythe robust equality of means test 


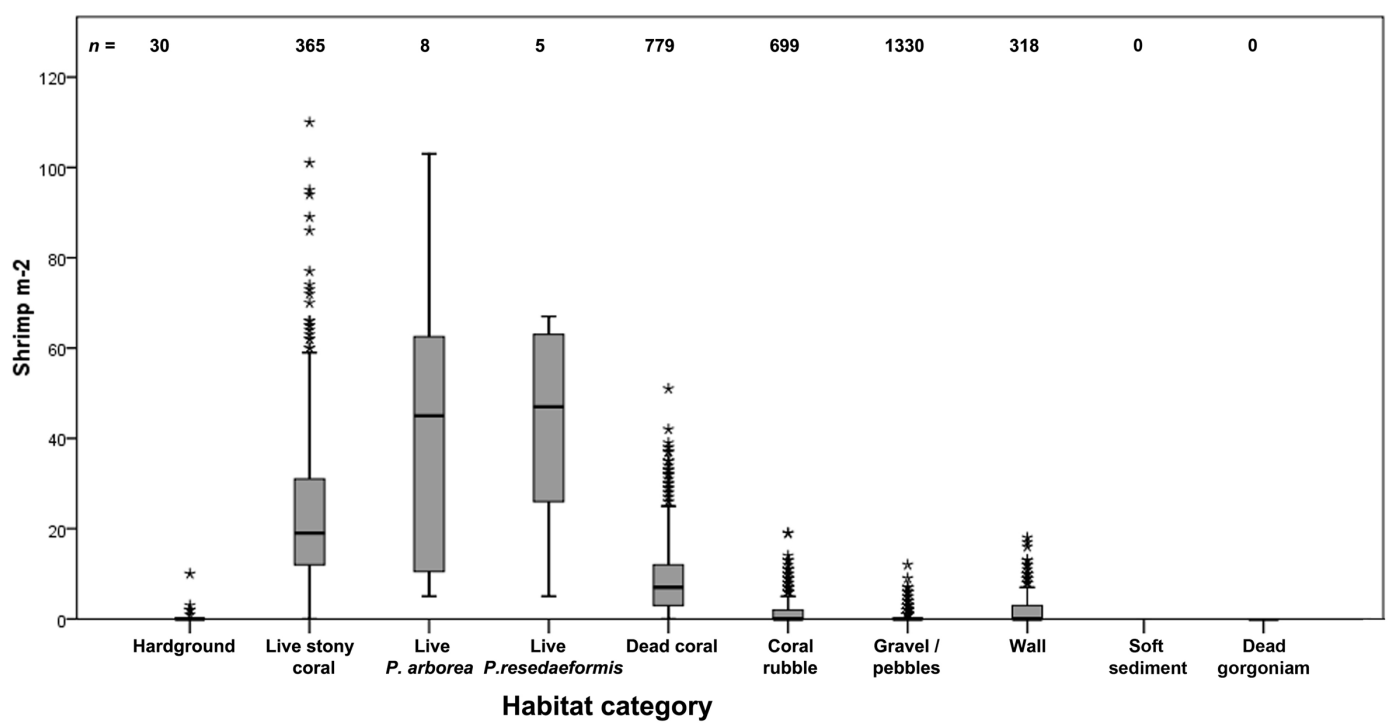

Fig. 6. Box plot showing observed median shrimp densities, quartiles and outliers observed in association with each of the investigated main microhabitat categories.

employed as Levene's test indicated the data to be inhomogeneous). The high $\omega^{2}$ indicates that the microhabitat category has a large effect on shrimp abundance at the Røst Reef. Bonferroni post hoc tests indicated that shrimp abundances were significantly higher in images containing predominantly live coral $(n=378$, mean $=25, \mathrm{SD}=19.4)$ than in images containing mainly dead coral structure $(n=779$, mean $=8.7$, $\mathrm{SD}=7.8)$, coral rubble $(n=699$, mean $=1.45, \mathrm{SD}=2.5)$ or non-biogenic microhabitat categories $(n=1678$, mean $=0.6$, $\mathrm{SD}=1.8)(p<0.01)$. The Bonferroni tests also showed that differences in shrimp abundances were also significant at the same confidence level between images containing predominantly dead coral structure and those containing mainly coral rubble. No significant difference was indicated between shrimp densities observed in images containing predominantly coral rubble microhabitat and those containing mainly non-biogenic microhabitats.

\subsection{Patterns of shrimp distribution}

The minimum, maximum, mean and median distance between individual shrimp within each microhabitat is given in Table 1. The mean distances to nearest-neighbour scores indicate a generally tighter arrangement of shrimp in association with living coral microhabitats than with dead coral structure or coral rubble microhabitats. Though shrimp tended to be more closely spaced in non-biogenic microhabitats, the low density of shrimp in these microhabitats probably indicates that the few shrimp present are utilising particular microhabitat features (such as pebble overhangs or fissures in a wall) rather than clustering together intentionally.

Sufficient shrimp densities to allow for Ripley's L analysis $\left(>20\right.$ individuals $\mathrm{m}^{-2}$ ) were observed in 267 image frames (Table 2). These high densities were only observed in association with live Lophelia pertusa, live Paragorgia arborea, live Primnoa resedaeformis and the dead scleractinian microhabitats. Table 2 shows that within just over $50 \%$ of the images classified as being predominantly live Lophelia pertusa microhabitat, $>20$ shrimp $\mathrm{m}^{-2}$ were observed, with higher percentages of live Paragorgia arborea $(62.5 \%)$ and live Primnoa resedaeformis $(80 \%)$ microhabitat image frames also containing shrimp densities of $>20$ shrimp m$^{-2}$. Just under $10 \%$ of dead scleractinian structure image frames contained $>20$ shrimp $\mathrm{m}^{-2}$. Table 2 shows that on a scale of $<10 \mathrm{~cm}$, shrimp were more negatively associated with their neighbours in live coral microhabitat image frames than in dead coral microhabitat frames. At scales of $>10 \mathrm{~cm}$, shrimp were observed to be clustered across all microhabitats, within image frames with $>20$ shrimp $\mathrm{m}^{-2}$ present.

\subsection{Microhabitat complexity and shrimp abundance}

Frames containing $>1$ microhabitat category had a significantly greater number of shrimp present than those with only 1 microhabitat category present, $H(3)=1052.54, p<0.01$, Fig. 7. Densities of shrimp in images containing 2,3 or $4+$ microhabitat categories were not significantly different from each other.

\section{Discussion}

\subsection{Shrimp abundance and microhabitat}

From the results presented here it would appear that shrimp densities vary across the Røst Reef complex with change in microhabitat category, and that the type of microhabitat 


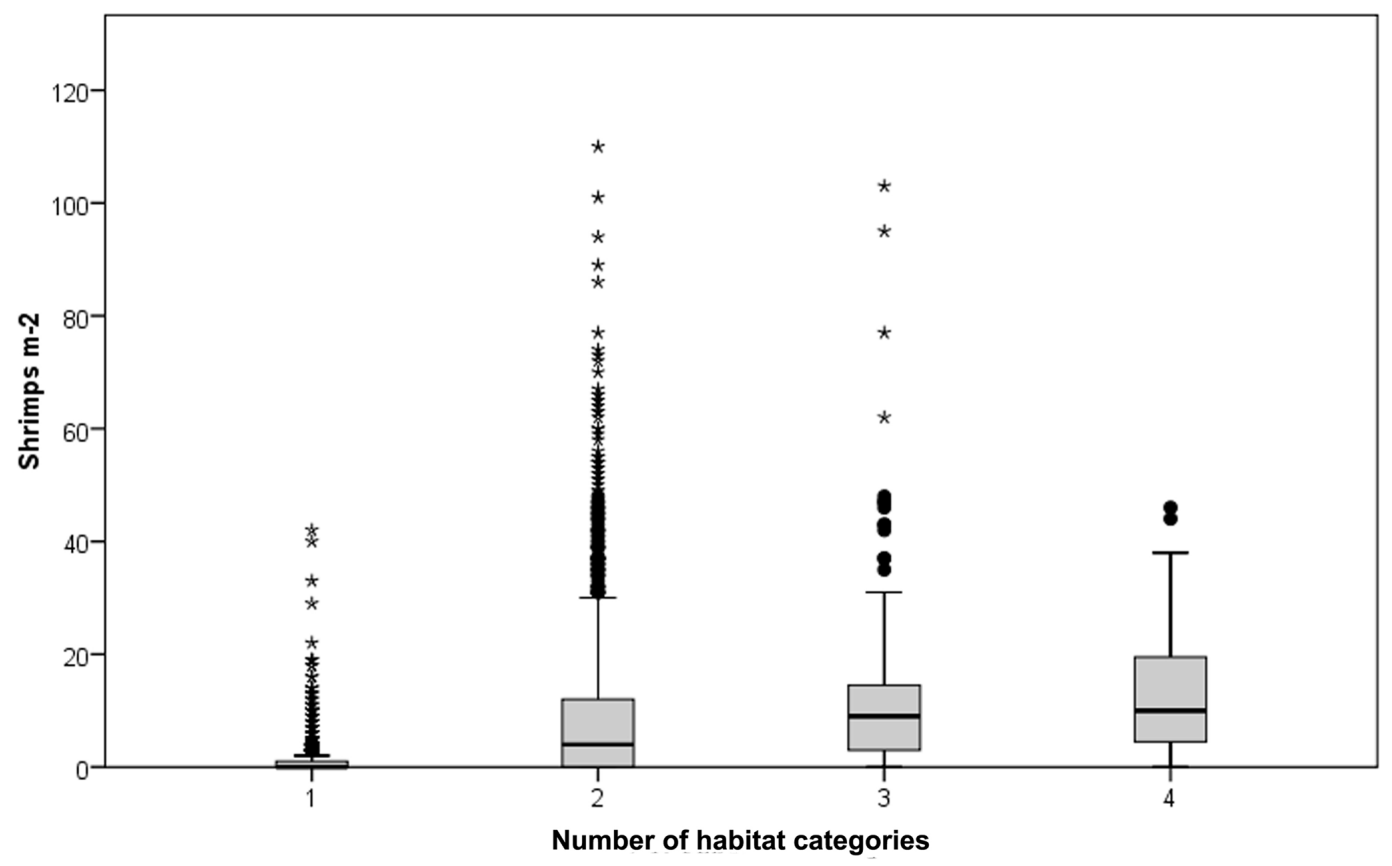

Fig. 7. Box plot showing shrimp densities observed in image frames with differing numbers of microhabitat categories present.

can have a large influence on shrimp density. From the images analysed, shrimp abundances appear highest in regions where the available microhabitat is predominantly live coral, with a mean average density of 25 shrimp m ${ }^{-2}$ $(\mathrm{SD}=19.4)$ recorded. The live reef microhabitat is perhaps the most physically complex (Buhl-Mortensen et al., 2010). Dead coral structure, though still angular and providing physical niches over a range of scales, was associated with shrimp abundances $\sim 60 \%$ lower than observed in association with the live coral microhabitats (mean shrimp $\mathrm{m}^{-2}=8.7, \mathrm{SD}=7.8$ ). It is unlikely that this difference can be explained by observer bias or shrimp behaviour, given that shrimp eyes were marginally easier to distinguish against dead coral structure than against live coral. Shrimp abundances were lower again in association with the coral rubble microhabitat (mean shrimp $\mathrm{m}^{-2}=1.45, \mathrm{SD}=2.5$ ) and nonbiogenic microhabitat categories (mean shrimp $\mathrm{m}^{-2}=0.6$, $\mathrm{SD}=1.8$ ). Coral rubble regions of CWC ecosystems consist of small, broken pieces of coral, partially eroded and lying on the seabed. Though this microhabitat contains small structural gaps between fragments which shrimp may occupy, it is difficult to imagine that shrimp utilising these could account for the considerable differences in density observed between this microhabitat and those observed in association with live coral microhabitats. The non-biogenic microhabitat categories, those not dependant on CWC reef development, i.e. hard ground outcrops, gravel/pebble fields and walls, exhibited the lowest abundances of shrimp observed though some areas of wall microhabitat had densities of several shrimp $\mathrm{m}^{-2}$ (Fig. 6). The statistically significant obser- vation of higher shrimp densities in images containing $>1$ microhabitat category is a further indication that increased local heterogeneity may be of benefit to CWC shrimp, as has been observed for shrimp in sublittoral environments (Hewitt et al., 2005).

Whether the shrimp are of benefit to the living Lophelia pertusa is not clear from this study. It is possible that they play a useful role in keeping the branches of Lophelia pertusa free from accumulating sediment, as has been hypothesised for associated polychaetes (Mortensen, 2001), a process which can lead to tissue damage over time if unchecked (Larsson and Purser, 2011). No attempt was made here to differentiate shrimp species from the video data, and potentially different species could be utilising the live coral and dead coral microhabitats. Spatial partitioning of the reef ecosystem by shrimp species has been reported at tropical coral reefs (Hoeksema and Fransen, 2011). A recent trawl survey done by D'Onghia et al. (2010) comparing species abundances within and outside of CWC reef zones indicated that such partitioning may also be likely at CWC reefs. They report comparable densities of the shrimp species Aristaeomorpha foliacea within and surrounding CWC habitat, the complete absence of particular shrimp species, (e.g. Aristeus antennatus) from within the reef itself but presence in the surrounding waters, and a 10-times-greater abundance of the commercially significant species Parapenaeus longirostris within the living reef structural area. Their paper reports observations from a Mediterranean reef, and the situation may be different on the Norwegian margin. The shrimp species commonly reported to occur within deep Norwegian 
waters (Hopkins and Nilssen, 1990) are generally those reported from CWC environments (Dons, 1944; Burdon-Jones and Tambs-Lyche, 1960; Jensen and Frederiksen, 1992; summarised in Mortensen and Fosså, 2006; Jonsson et al., 2004) indicating, as commonly reported for sessile fauna, a general lack of endemism in CWC reefs on the Norwegian margin (Burdon-Jones and Tambs-Lyche, 1960; Jensen and Frederiksen, 1992). Given the great variability in survey methods employed in the reports published to date, however, it is not easy to draw any conclusions on the differences in species densities (or indeed, total shrimp densities) on and off reefs.

Shrimp densities observed in association with Paragorgia arborea and Primnoa resedaeformis were similar, though the number of frames containing either of these coral species as the predominant microhabitat category were low (Table 1), rendering quantitative statistical analysis difficult. Such comparable densities would not be expected if shrimp were simply utilising the underlying microhabitat (the gorgonian coral) as an elevated surface on which to rest and attain a more favourable position with respect to the prevalent flow conditions, as the growth morphs and vertical colony extent of these gorgonian species is very different. Mortensen and Buhl-Mortensen (2005) indicated that Paragorgia arborea and Primnoa resedaeformis likely utilise different food sources. Paragorgia arborea colonies tend to stand near vertically, facing into the prevalent current and capturing food delivered by the stronger, less turbid currents found tens of centimetres above the seafloor, whereas Primnoa resedaeformis colonies may acquire their food supply from more turbid waters found in closer proximity to the seafloor. Possibly the elevated shrimp densities observed on both gorgonian corals are the result of shrimp feeding on material trapped within the mucus secreted by the corals (Patton, 1972), rather than material in the water column. Such a strategy would likely have led shrimp to preferentially occupy Paragorgia arborea rather than Primnoa resedaeformis - a behavioural trend unsupported by the data here.

The differences in Lophelia pertusa, Paragorgia arborea and Primnoa resedaeformis colony morphologies may account for the differences in shrimp abundances observed in frames containing predominantly these microhabitats. The more flexible gorgonian corals may provide a greater surface area for shrimp to rest on, and/or a more suitable set of refuges for evasion of predators (a behaviour in CWC shrimp hypothesised in Buhl-Mortensen and Mortensen, 2004a). In addition to the gorgonians, scleractinian CWCs also exude mucus as a cleaning agent and potentially as a food-gathering mechanism (Reitner, 2005; Wild et al., 2008; Purser et al., 2010). Should CWC shrimp be utilising material entrapped by the corals as a food source, then some difference in the food value of the mucus or the entrapped material found on scleractinians and gorgonians could explain the minor differences in shrimp densities observed in the coral species' microhabitats (Fig. 6).
Previous studies have investigated megafauna associated with Paragorgia arborea and Primnoa resedaeformis in western Atlantic waters (Metaxas and Davis, 2005; BuhlMortensen and Mortensen, 2005). Buhl-Mortensen and Mortensen (2005) reported on the difficulties involved in quantifying shrimp densities in the vicinity of these gorgonian species by either suction sampling fauna from coral branches or by counting those collected whilst sampling whole coral branches. From video taken by ROV, BuhlMortensen and Mortensen (2005) report shrimp densities of 4.8 and 3.1 individuals colony $^{-1}$ in association with Paragorgia arborea and Primnoa resedaeformis respectively. These density estimates are far lower than those reported in the current study, and made from video data recorded by a more intrusive methodology. In the Gulf of Alaska, Krieger and Wing (2002) reported "hundreds of shrimp eyes" reflected from within the branches of Primnoa spp. colonies - although not a strictly quantitative estimate of shrimp density, their rough estimate is comparable with shrimp densities associated with the living gorgonian microhabitats presented here, from the eastern side of the Atlantic. Should protection be the overriding advantage offered by living coral microhabitats over the surrounding dead reef areas, then the complexity and malleability of the Primnoa resedaeformis structure may be the most appealing coral microhabitat for smaller shrimp individuals and species. It has been hypothesised that this species is used as a refuge by shrimp $<3 \mathrm{~cm}$ in the Gulf of Alaska (Krieger and Wing, 2002). Although in the current study it is not possible to observe statistically significant differences in shrimp abundances between the two investigated gorgonian species, it is quite possible that the video data under-sampled shrimp to a greater degree in frames dominated by Primnoa resedaeformis than in frames where the less spatially complex Paragorgia arborea coral was in dominance. The spaced, branched morphologies of the gorgonians may offer more useful refuge niches than the more densely packed Lophelia pertusa structure, perhaps limiting this microhabitat in usefulness to larger shrimp individuals and species. The number of image frames containing either of the gorgonian species $(n=5-8)$ analysed in this study was far less than frames containing live Lophelia pertusa $(n=365)$, so without further study, the hypothesis that higher densities of shrimp are associated with the gorgonian corals should be approached tentatively.

\subsection{Shrimp distribution within microhabitats}

The observation that shrimp at the Røst Reef preferentially occupy regions of living coral has previously been reported as a likely behavioural trend in mobile CWC reef filter feeders (Buhl-Mortensen et al., 2010), and reported for some shrimp species in the Mediterranean (D'Onghia et al., 2011). Elevated shrimp concentrations observed following direct sampling of associate fauna from within Lophelia pertusa living coral structure from the Gulf of Mexico (Cordes et 
al., 2008) led the authors to hypothesise that some shrimp species may play a role as cleaners at CWC reefs, as has been observed in tropical reefs (Zann, 1987). At tropical reefs, studies of stomach contents of coral-associated shrimp individuals have indicated a diet consisting of both coral mucus and zooplankton (Patton, 1994). The regular shrimp spacing on the $<10 \mathrm{~cm}$ scale (i.e. a tendency to maintain some distance from neighbouring shrimp over distances of less than $10 \mathrm{~cm}$ ) found in this current study within live coral microhabitats may indicate that individual shrimp require a minimum surrounding space for feeding, or may be a consequence of social interaction (Henry et al., 2013). It is also possible that the regularity of spacing observed is a function of the underlying coral morphology. Given the differences in shrimp densities observed in association with living Lophelia pertus $a$ and dead scleractinian structure microhabitats, the feeding hypotheses seem the more likely causes considering that the physical structure of the live Lophelia pertusa and dead coral structure microhabitats are not hugely different.

\section{Summary}

Despite the absence of species-level distribution data and the variation in seabed coverage area of the various microhabitat categories investigated here, it would appear that shrimp densities can vary significantly across Norwegian margin CWC reefs with changes in microhabitat, and that the spacing of shrimp within a microhabitat can also differ between microhabitat categories. The significance of biogenic reef microhabitats for shrimp is very clear, with shrimp densities observed in association with these (live Lophelia pertusa, live Paragorgia arborea, live Primnoa resedaeformis, dead coral structure, coral rubble) in excess of an order of magnitude greater than observed in association with the non-biogenic microhabitats at the Røst Reef (gravel/pebbles, wall, hard ground). What is not clear from this study is whether or not a temporal factor may also determine spatial arrangement and abundances of shrimp within or between microhabitats. The video data used were also of insufficient quality to allow for identification of shrimp to species level, though the image analysis techniques used here would be suitable for differentiating between shrimp species when higher quality video data are available in the future.

Given the high densities of shrimp identified in association with the biogenic microhabitats investigated in this study, it would seem likely that the loss of CWC reefs via anthropogenic activity or otherwise would have a knock-on effect on local fish stocks, in addition to that associated with the loss of structural fish microhabitat. With the high shrimp densities observed here in association with biogenic microhabitats, it would seem likely that the loss of CWC reef ecosystems would result in a drop in local shrimp numbers, and therefore a reduction in prey availability for many fish species.
Acknowledgements. The research leading to these results has received funding from the European Community's Seventh Framework Programme (FP7/2007-2013) under the HERMIONE project, grant agreement No. 226354) with further funding received from Statoil. This work is a CORAMM group collaboration. The captain, crew and on board scientific party of the RV Polarstern ARKXXII/1a cruise are thanked for their assistance, particularly B. Lessmann for assistance with preparation of the video data. We would also like to thank the anonymous reviewers, who spent time with this manuscript and provided reports which allowed for us to make significant improvements to the text.

Edited by: A. Freiwald

\section{References}

Ballion, S., Hamel, J-F., Wareham, V. E., and Mercier, A.: Deep cold-water corals as nurseries for fish larvae, Front. Ecol. Environ., 10, 351-356, 2012.

Bergmann, M., Langwald, N., Klages, M., Ontrup, J., and Nattkemper, T. W.: Megafaunal assemblages from two shelf stations west of Svalbard, Mar. Biol. Res., 7, 525-539, 2011.

Bongiorni, L., Mea, M., Gambi, C., Pusceddu, A., Taviani, M. and Danovaro, R.: Deep-water scleractinian corals promote higher biodiversity in deep-sea meiofaunal assemblages along continental margins, Biol. Conserv., 143, 1687-1700, 2010.

Brown, M. B. and Forsythe, A. B.: The small sample behaviour of some statistics which test the equality of several means, Technometrics, 16, 129-132, 1974.

Buhl-Mortensen, L. and Mortensen, P. B.: Crustaceans associated with the deep-water gorgonian Paragorgia arborea (L., 1758) and Primnoa resedaeformis (Gunnerus, 1763), J. Nat. His., 38, 1233-1247, 2004a.

Buhl-Mortensen, L. and Mortensen, P. B.: Symbiosis in deep-water corals, Symbiosis, 37, 33-61, 2004b.

Buhl-Mortensen, L. and Mortensen, P. B.: Distribution and diversity of species associated with deep-sea gorgonian corals off Atlantic Canada, in: Cold-water corals and ecosystems, edited by: Freiwald, A. and Roberts, J. M., Springer, Berlin, 849-879, 2005.

Buhl-Mortensen, L., Vanrusel, A., Gooday, A. J., Levin, L. A., Priede, I. G., Mortensen, P-B., Gheerardyn, H., King, N. J., and Raes, M.: Biological structures as a source of habitat heterogeneity and biodiversity on the deep ocean margins, Mar. Ecol-Evol. Persp., 31, 21-50, 2010.

Burdon-Jones, C., and Tambs-Lyche, $\mathrm{H}$ : Observations on the fauna of the North Brattholmen stone-coral reef near Bergen. Arbok for Universitet I Bergen, Matematisk-naturvitenskaplig Serie., 4, 1-24, 1960.

Cordes, E. E., McGinley, M. P., Podowski, E. L., Becker, E. L., Lessard-Pilon, S., Viada, S. T., and Fisher, C. R.: Coral communities of the deep Gulf of Mexico, Deep-Sea Res. Pt. I, 55, 777-787, 2008.

Costello, M., McCrea, M., Freiwald, A., Lundälv, T., Jonsson, L., Bett, B. J., van Weering, T. C. E., de Hass, H., Roberts, J. M., and Allen, D.: Role of cold-water Lophelia pertusa coral reefs as fish habitat in the NE Atlantic, in: Cold-water corals and ecosystems, edited by Freiwald, A. and Roberts, J.M., Springer, Berlin, 771805, 2005. 
Davies, A. J., Duineveld, G. C. A., Lavaleye, M. S. S., Bergman, M. J. N., van Haren, H., and Roberts, J. M.: Downwelling and deep-water bottom currents as food supply mechanisms to the cold-water Lophelia pertusa (Scleractinia) at the Mingulay Reef complex, Limnol. Oceanogr., 54, 620-629, 2009.

De Mol, B., Van Rensbergen, P., Pillen, S., Van Herreweghe, K., Van Rooij, D., McDonnell, A., Huvenne, V., Ivanov, M., Swennen, R., and Henriet, J. P.: Large deep-water coral banks in the Porcupine Basin, southwest of Ireland, Mar. Geol., 188, 193-231, 2002.

D’Onghia, G., Mairorano, P., Sion, L., Giove, F., Capezzuto, F., Carlucci, R., and Tursi, A.: Effects of deep-water coral banks on the abundance and size structure of the megafauna in the Mediterranean Sea, Deep-Sea Res. Pt. I, 57, 397-411, 2010.

D’Onghia, G, Indennidate, A, Giove, A., Savini, A, Capezzuto, F., Sion, L., Vertino, A., and Maiorano, P.: Distribution and behaviour of deep-sea benthopelagic fauna observed using towed cameras in the Santa Maria di Leuca cold-water coral province, Mar. Ecol. Prog. Ser., 443, 95-110, 2011.

D’Onghia, G., Maiorano, P., Carlucci, R., Capezzuto, F., Carluccio, A., and Sion, L.: Comparing deep-sea fish fauna between coral and non-coral "Megahabitats" in the Santa Maria di Leuca cold-water coral province (Mediterranean Sea), PLoS ONE, 7, e44509, doi:10.1371/journal.pone.0044509, 2012.

Dons, C.: Norges korallrev, Det kongelige norske videnskabers selskabs forhandlinger, 16, 37-82, 1944.

Dorschel, B., Hebbeln, D., Rüggeberg, A., Dullo, W. C., and Freiwald, A.: Growth and erosion of a cold-water coral covered carbonate mound in the Northeast Atlantic during the Late Pleistocene and Holocene, Earth Planet. SC. Lett., 233, 33-44, 2005.

Duineveld, G. C. A., Lavaleye, M. S. S., and Berghuis, E. M.: Particle flux and food supply to a seamount cold-water coral community (Galicia Bank, NW Spain), Mar. Ecol. Prog. Ser., 277, 13-23, 2004.

Duineveld, G. C. A., Jeffreys, R. M., Lavaleye, M. S. S., Davies, A. J., Bergman, M. J. N., Watmough, T., and Witbaard, R.: Spatial and tidal variation in food supply to shallow cold-water coral reefs of the Mingulay Reef Complex (Outer Hebrides, Scotland), Mar. Ecol. Prog. Ser., 444, 97-115, 2012.

Field, A.: Discovering statistics using SPSS, SAGE publications, London, UK, 822 pp., 2009.

Fosså, J. H. and Skjoldal, H. R.: Conservation of cold-water coral reefs in Norway, in: Handbook of marine fisheries conservation and management, edited by: Grafton, R. Q., Hilborn, R., Squires, D., Tait, M., and Williams, M., Oxford University Press, UK, 215-240, 2010.

Fosså, J. H., Mortensen, P. B., and Furevik, D. M.: The deep-water coral Lophelia pertusa in Norwegian waters: distribution and fishery impacts, Hydrobiologia, 471, 1-12, 2002.

Fosså, J. H., Lindberg, B., and Christensen, O.: Mapping of Lophelia reefs in Norway: experiences and survey methods, in: Cold-water corals and ecosystems, edited by: Freiwald, A. and Roberts, J. M., Springer, Berlin, 359-391, 2005.

Freiwald, A., Hühnerbach, V., Lindberg, B., Wilson, J. B., and Campbell, J.: The Sula Reef complex, Norwegian shelf, Facies, 47, 179-200, 2002.

Gheerardyn, H., De Troch, M., Vincx, M., and Vanreusel, A.: Diversity and community structure of harpacticoid copepods associated with cold-water coral substrates in the Porcupine Seabight
(North-East Atlantic), Helgoland Mar. Res., 64, 53-62, 2010.

Henry, L. A.: Hydroids associated with deep-sea corals in the boreal north-west Atlantic, J. Mar. Biol. Assoc. UK, 81, 163-164, 2001.

Henry, L. A. and Roberts, J. M.: Biodiversity and ecological composition of macrobenthos on cold-water coral mounds and adjacent off-mound habitat in the bathyal Porcupine Seabight, NE Atlantic, Deep-Sea Res. Pt. 1, 54, 654-672, 2007.

Henry, L. A., Davies, A. J., and Roberts, J. M.: Beta diversity of cold-water coral reef communities off western Scotland, Coral Reefs, 29, 427-436, 2010.

Henry, L. A., Moreno Navas, J., and Roberts, J. M.: Multi-scale interactions between local hydrography, seabed topography, and community assembly on cold-water coral reefs, Biogeosciences, 10, 2737-2746, doi:10.5194/bg-10-2737-2013, 2013.

Herrera, S., Shank, T. M., and Sanchez, J. A.: Spatial and temporal patterns of genetic variation in the widespread deepsea coral Paragorgia arborea, Mol. Ecol., 21, 6053-6067, doi:10.1111/mec.12074, 2012.

Hewitt, J. E., Thrush, S. F., Halliday, J., and Duffy, C.: The importance of small-scale habitat structure for maintaining beta diversity, Ecology, 86, 1619-1626, 2005.

Hoeksema, B. W. and Fransen, C. H. J. M.: Space partitioning by symbiotic shrimp species cohabitating in the mushroom coral Heliofungia actiniformis at Semporna, eastern Sabah, Coral Reefs, 30, p. 519, 2011.

Hopkins, C. C. E. and Nilssen, E. M.: Population biology of the deep-water prawn (Pandalus borealis) in Balsfjord, northern Norway: I. Abundance, mortality, and growth, 1979-1983, J. Cons. Int. Explor. Mer., 47, 148-166, 1990.

Husebø, A., Nøttestad, L., Fosså, J. H., Furevik, D. M., and Jørgensen, S. B.: Distribution and abundance of fish in deep-sea coral habitats, Hydrobiologica, 471, 91-99, 2002.

Jensen, A. and Frederiksen R.: The fauna associated with the bankforming deepwater coral Lophelia pertusa (Scleractinaria) on the Faroe shelf, Sarsia, 77, 53-69, 1992.

Jonsson, L. G., Nilsson, P. G., Floruta, F., and Lundälv, T.: Distributional patterns of macro- and megafauna associated with a reef of the cold-water coral Lophelia pertusa on the Swedish west coast, Mar. Ecol. Prog. Ser., 284, 163-171, 2004.

Kiriakoulakis, K., Fisher, E., Wolff, G. A., Freiwald, A., Grehan, A., and Roberts, J. M.: Lipids and nitrogen isotopes of two deep-water corals from the North-East Atlantic: initial results and implications for their nutrition, in: Cold-water corals and ecosystems, edited by: Freiwald, A. and Roberts, J. M., Springer, Berlin, 715-729, 2005.

Kiriakoulakis, K., Freiwald, A., Fisher, E., and Wolff, G.: Organic matter quality and supply to deep-water coral/mound systems of the NW European Continental Margin, Int. J. Earth Sci., 96, 159170, 2007.

Klages, M. and Thiede, J.: The expedition of the research vessel "Polarstern" to the Arctic in 2007 (ARK-XXII/1a-c) Berichte zur polar- und meeresforschung (Reports on polar and marine research), Bremerhaven, Alfred Wegener Institute for Polar and Marine Research, 2011.

Krieger, K. J. and Wing, B. L.: Megafauna associations with deepwater corals (Primnoa spp.) in the Gulf of Alaska, Hydrobiologica, 471, 83-90, 2002.

Laberg, J. S. and Vorren, T. O.: The Trænadjupet Slide, offshore Norway - morphology, evacuation and triggering mechanisms, 
Mar. Geol., 171, 95-114, 2000.

Larsson, A. I. and Purser, A.: Sedimentation on the cold-water coral Lophelia pertusa: Cleaning efficiency from natural sediments and drill cuttings, Mar. Poll. Bull., 62, 1159-1168, 2011.

Le Guilloux, E., Hall-Spencer, J. M., Söffker, M. K., and Olu, K.: Gastroptychus formosus and cold-water corals in the North Atlantic, J. Mar. Biol. Assoc. UK., 90, 1363-1369, 2010.

Lessard-Pilon, S. A., Podowski, E. L., Cordes, E. E., and Fisher, C. R.: Megafauna community composition associated with Lophelia pertusa colonies in the Gulf of Mexico, Deep-Sea Res. Pt II, 57, 1882-1890, 2010.

Levin, L. A. and Sibuet, M.: Understanding continental margin biodiversity: A new imperative, Annu. Rev. Marine. Sci., 4, 79-112, 2012.

López Correa, M., Freiwald, A., Hall-Spencer, J., and Taviani, M.: Distribution and habitats of Acesta excavata (Bivalvia: Limidae) with new data on its shell ultrastructure, in: Cold-water corals and ecosystems, edited by: Freiwald, A. and Roberts, J. M., Springer, Berlin, 173-205, 2004.

Metaxas, A. and Davis, J.: Megafauna associated with assemblages of deep-water gorgonian corals in Northeast Channel, off Nova Scotia, Canada, J. Mar. Biol. Assoc. UK., 85, 1381-1390, 2005.

Mortensen, P. B.: Aquarium observations of the deep-water coral Lophelia pertusa (L., 1758) (scleractinia) and selected associated invertebrates, Ophelia, 54, 83-104, 2001.

Mortensen, P. B. and Buhl-Mortensen, L.: Morphology and growth of the deep-water gorgonians Primnoa resedaeformis and Paragorgia arborea, Mar. Biol., 147, 775-788, 2005.

Mortensen, P. B. and Fosså, J. H.: Species diversity and spatial distribution of invertebrates on Lophelia reefs in Norway, Proceedings of the 10th International Coral Reef Symposium, Okinawa, Japan, 1849-1868, 2006.

Mortensen, P. B., Hovland, M., Brattegard, T., and Farestveit, R.: Deep water bioherms of the scleractinian coral Lophelia pertusa (L.) at $64 \mathrm{~N}$ on the Norwegian shelf: structure and associated megafauna, Sarsia, 80, 145-158, 1995.

Mortensen, P. B., Roberts, J. M., and Sundt, R. C.: Video-assisted grabbing: a minimally destructive method of sampling azooxanthellate coral banks, J. Mar. Biol. Assoc. UK, 80, 365-366, 2000.

Mortensen, P. B., Hovland, M., Fosså, J. H., and Furevik, D. M.: Distribution, abundance and size of Lophelia pertusa in midNorway in relation to seabed characteristics, J. Mar. Biol. Assoc. UK, 81, 581-597, 2001.

Nordgulen, O, Bargel, T. H., Longva, O., and Ottesen, D.: A preliminary study of Lofoten as a potential World Heritage Site based on natural criteria, Geological Survey of Norway, 2006.

Ontrup, J., Ritter, H., Scholz, S. W., and Wagner, R.: BIIGLE Web 2.0 enabled labeling and exploring of images from the Arctic deep-sea observatory HAUSGARTEN, Proc. OCEANS '09, IEEE, Bremen, 2009.

Orejas, C., Gori, A., Lo Iacono, C., Puig, P., Gili, J.-M., and Dale, M. R. T.; Cold-water corals in the Cap de Creus canyon, northwestern Mediterranean: spatial distribution, density and anthropogenic impact, Mar. Ecol. Prog. Ser., 397, 37-51, 2009.

Patton, W. K.: Studies on the animal symbionts of the gorgonian coral, Leptogorgia virgulata (Lamark), B. Mar. Sci., 22, 419431, 1972.

Patton, W. K.: Distribution and ecology of animals associated with branching corals (Acropora SPP) from the Great Barrier Reef,
Australia, B. Mar. Sci., 55, 193-211, 1994.

Purser, A., Bergmann, M., Lundälv, T., Ontrup, J., and Nattkemper, T.: Use of machine-learning algorithms for the automated detection of cold-water coral habitats: a pilot study, Mar. Ecol. Prog. Ser., 397, 241-251, 2009.

Purser, A., Larsson, A. I., Thomsen, L., and Van Oevelen, D.: The influence of flow velocity and food concentration on Lophelia pertusa (Scleractinia) zooplankton capture rates, J. Exp. Mar. Biol. Ecol., 395, 55-62, 2010.

Raes, M. and Vanreusel, A.: Microhabitat type determines the composition of nematode communities associated with sedimentclogged cold-water coral framework in the Porcupine Seabight (NE Atlantic), Deep-Sea Res. Pt. II, 53, 1880-1894, 2006.

Reed, J. K., Gore, R. H., Scotto, L. E., and Wilson, K. A.: Community composition, structure, areal and trophic relationships of decapods associated with shallow- and deep-water Oculina varicosa coral reefs, B. Mar. Sci., 32, 761-786, 1982.

Reitner, J.: Calcifying extracellular mucus substances (EMS) of Madrepora oculata - a first geobiological approach, in: Coldwater corals and ecosystems, edited by Freiwald, A. and Roberts, J. M., Springer, Berlin, 731-744, 2005.

Ripley, B. D.: The second-order analysis of stationary point processes, J. Appl. Probab., 13, 255-266, 1976.

Reveillaud, J., Freiwald, A., Van Rooij, D., Le Guilloux, E., Altuna, A., Fourbert, A., Vanreusel, A., Olu-Le Roy, K., and Henriet, J. P.: The distribution of scleractinian corals in the Bay of Biscay, NE Atlantic, Facies, 54, 317-331, 2008.

Roberts, J. M., Wheeler, A. J., and Freiwald, A.: Reefs of the deep: The biology and geology of cold-water coral ecosystems, Science, 312, 543-547, 2006.

Roberts, J. M., Henry, L. A., Long, D., and Hartley, J. P.: Coldwater coral reef frameworks, megafuanal communities and evidence for coral carbonate mounds on the Hatton Bank, north east Atlantic, Facies, 54, 297-316, 2008.

Roberts, J. M., Wheeler, A., Freiwald, A., and Cairns, S.: ColdWater Corals. The biology and geology of deep-Sea coral habitats, Cambridge, UK, 2009.

Rogers, A. D.: The biology of Lophelia pertusa (LINNAEUS 1758) and other deep-water reef-forming corals and impacts from human activities, Int. Rev. Hydrobiol., 84, 315-406, 1999.

Ross, S. W. and Quattrini, A. M.: The fish fauna associated with deep coral banks off the southeastern United States, Deep-Sea Res. Pt I, 54, 975-1007, 2007.

Rüggeberg, A., Flögel, S., Dullo, W. C., Hissmann, K., and Freiwald, A.: Water mass characteristics and sill dynamics in a subpolar cold-water coral reef setting at Stjernsund, northern Norway, Mar. Geol., 282, 5-12, 2010.

Schoening, T., Ehnert, N., Ontrup, J., and Nattkemper, T. W.: BIIGLE Tools - A Web 2.0 Approach for Visual Bioimage Database Mining, IV09 Intl. Conference on Information Visualisation, Barcelona, Spain, 2009.

Schoening, T., Bergmann, M., Ontrup, J., Taylor, J., Dannheim, J., Gutt, J., Purser, A., and Nattkemper, T. W.: Semi-automated image analysis for the assessment of megafaunal densities at the Arctic deep-sea observatory HAUSGARTEN, PLoS ONE, 7, e38179, doi:10.1371/journal.pone.0038179, 2012.

Söffker, M., Sloman, K. A., and Hall-Spencer, J. M.: In situ observations of fish associated with coral reefs off Ireland, Deep-Sea Res. Pt I, 58, 818-825, 2011. 
Thiem, Ø., Ravagnan, E., Fosså, J. H., and Berntsen, J.: Food supply mechanisms for cold-water corals along a continental shelf edge, J. Marine Syst. 60, 207-219, 2006.

Tong, R., Purser, A., Unnithan, V., and Guinan, J.: Multivariate Statistical Analysis of Distribution of Deep-Water Gorgonian Corals in Relation to Seabed Topography on the Norwegian Margin, PLoS ONE 7, e43534, doi:10.1371/journal.pone.0043534, 2012a.

Tong, R., Purser, A., and Unnithan, V.: Predicting habitat suitability for cold-water coral Lophelia pertusa using multiscale terrain variables, in: Earth system science: Bridging the gaps between disciplines, edited by: Lohman, G., Grosfeld, K., Wolf-Gladrow, D., and Unnithan, V., Springer, Berlin, 113-117, 2012 b.

Trenkel, V. M., Chris Francis, R. I. C., Lorance, P., Mahévas, S., Rochet, M. J., and Tracey, D. M.: Availability of deep-water fish trawling and visual observation from a remotely operated vehicle (ROV), Mar. Ecol. Prog. Ser., 284, 293-303, 2004.

Turley, C. M., Roberts, J. M., and Guinotte, J. M.: Corals in deepwater: will the unseen hand of ocean acidification destroy coldwater ecosystems? Coral Reefs, 26, 445-448, 2007.

Van Oevelen, D., Duineveld, G., Lavaleye, M., Mienis, F., Soetaert, K., and Heip, C. H. R.: The cold-water coral community as a hot spot for carbon cycling on continental margins: A food-web analysis from Rockall Bank (northeast Atlantic), Limnol. Oceanogr., 54, 1829-1844, 2009.

Wagner, H., Purser, A., Thomsen, L., Jesus, C. C., and Lundälv, T.: Particulate organic matter fluxes and hydrodynamics at the Tisler cold-water coral reef, J. Mar. Sys., 85, 19-29, 2011.
Weaver, P. P. E, Billett, D. S. M., Boetius, A., Danovaro, R., Freiwald, A., and Sibuet, M.: Hotspot ecosystem research on Europe's deep-ocean margins, Oceanography, 17, 132-143, 2004.

Wehrmann, L. M., Knab, N. J., Pirlet, H., Unnithan, V., Wild, C., and Ferdelman, T. G.: Carbon mineralization and carbonate preservation in modern cold-water coral reef sediments on the Norwegian shelf, Biogeosciences, 6, 663-680, doi:10.5194/bg6-663-2009, 2009.

Wheeler, A.J., Beyer, A., and Freiwald, A.: Morphology and environment of deep-water coral mounds on the NW European margin, Int. J. Earth Sci., 96, 37-56, 2007.

White, M.: Benthic dynamics at the carbonate mound regions of the Porcupine Sea Bight continental margin, Int. J. Earth Sci., 96, $1-9,2007$.

White, M., Wolff, G. A., Lundälv, T., Guihen, D., Kiriakoulakis, K., Lavaleye, M., and Duineveld, G.: cold-water coral ecosystem (Tisler Reef, Norwegian Shelf) may be a hotsport for carbon cycling, Mar. Ecol. Prog. Ser., 465, 11-23, 2012.

Wild, C., Mayr, C., Wehrmann, L., Schöttner, S., Naumann, M., Hoffmann, F., and Rapp, H. T.: Organic matter release by cold water corals and its implication for fauna-microbe interaction, Mar. Ecol. Prog. Ser., 372, 67-75, 2008.

Zann, L. P.: A review of macrosymbiosis in the coral reef ecosystem, Int. J. Parasitol., 17, 399-405, 1987. 